\title{
EVALUATION OF THE SURFACE HARDNESS OF COMPOSITE RESINS BEFORE AND AFTER POLISHING AT DIFFERENT TIMES
}

\author{
AVALIAÇÃO DA DUREZA SUPERFICIAL DE RESINAS COMPOSTAS \\ ANTES E APÓS O POLIMENTO EM DIFERENTES TEMPOS
}

\begin{abstract}
Michelle Alexandra CHINELATTI ${ }^{1}$, Daniela Thomazatti CHIMELLO ${ }^{1}$, Renata Pereira RAMOS ${ }^{1}$, Regina Guenka PALMA-DIBB ${ }^{2}$
\end{abstract}

1- DDS, MSc, Post-graduate student, Department of Restorative Dentistry, Ribeirão Preto Dental School, University of São Paulo, Brazil. 2- DDS, MSc, PhD, Associate Professor, Department of Restorative Dentistry, Ribeirão Preto Dental School, University of São Paulo, Brazil.

Corresponding address: Michelle A. Chinelatti - Faculdade de Odontologia de Ribeirão Preto - USP - Departamento de Odontologia Restauradora - Av. do Café s/nº - Monte Alegre - Cep.: 14040-904, Ribeirão Preto - SP, Brasil - e-mail: michinelatti@gmail.com - phone: 5516-3602-4016 - fax: 55-16-3633-0999

Received: August 30, 2005 - Modification: January 17, 2006 - Accepted: March 09, 2006

\begin{abstract}
$P$

urpose: The aim of this study was to evaluate the surface hardness of six composite resins: Revolution, Natural Flow, Fill Magic Flow, Flow-it! (flowables), Silux Plus (microfilled) and Z100 (minifilled) before and after polishing at different times. Materials and Methods: For this purpose, 240 specimens (5mm diameter, $1.4 \mathrm{~mm}$ high) were prepared. Vickers hardness was determined before and after polishing at different times: immediately, 24h, 7 and 21 days after preparation of the samples. Statistical analysis was performed by ANOVA and Tukey test. Results: There was no difference in the hardness of flowable resins, which had lower hardness than the minifilled resin. The minifilled resin showed the highest surface hardness as compared to the other materials $(\mathrm{p}<0.01)$. All materials exhibited higher hardness after polishing, being more evident after 7 days. Conclusion: It may be concluded that, regardless of the composite resin, surface hardness was considerably increased when polishing was delayed and performed 1 week after preparation of the samples.
\end{abstract}

Uniterms: Hardness; Composite resins; Polishing.

\begin{abstract}
RESUMO
$P_{\text {roposi }}$

Magic Flow, Flow-it! (flowables), Silux Plus (micropartículas) e Z100 (híbrida) - antes e após o polimento realizado em diferentes tempos. Material e Método: Foram confeccionados 240 corpos-de-prova circulares (5mm de diâmetro e 1,4mm de altura). A dureza Vickers foi obtida antes e após o polimento realizado em diferentes tempos: imediatamente, 24 horas, 7 dias e 21 dias após a confecção do corpo-de-prova. Os dados foram analisados estatisticamente por meio da ANOVA e do Teste de Tukey. Resultados: Não houve diferença entre as resinas compostas flowable, as quais apresentaram os menores valores de dureza. A resina composta híbrida demonstrou os melhores resultados. Todos os materiais exibiram aumento de dureza após a realização do polimento, que foi mais evidente após 7 dias. Conclusão: Pôde-se concluir que, independente do tipo de resina composta, a dureza superficial foi consideravelmente maior quando o polimento foi realizado 1 semana após a confecção dos corpos-deprova.
\end{abstract}

Unitermos: Dureza; Resinas compostas; Polimento. 


\section{INTRODUCTION}

After shaping and polymerization, the surface of a dental composite restoration will normally remain rough ${ }^{28}$. Surface roughness allows plaque accumulation ${ }^{29}$, which may result in gingival inflammation, superficial staining and secondary caries. Proper surface finishing and polishing are critical clinic procedures, which enhance esthetics and longevity of restorations. Moreover, polishing reduces roughness and scratches created by finishing instruments ${ }^{30}$.

Although the esthetic restorative materials that are lightcured against a matrix strip are not devoid of imperfections, they present the smoothest surface that is possible to achieve $^{1,24}$. However, previous studies ${ }^{10,24}$ showed that hardness values for the celluloid strip-finished composites were lower than those of polished surfaces, probably due to the accumulation of organic matrix on the surface.

Since their introduction, composite resins have been continuously developed in an attempt to improve their properties and broaden their clinical applications. The properties of composite resins can be altered by variations in composition and amount of resin matrix, as well as size and distribution of filler particles ${ }^{2,5-8,15,18,25-27}$. The greatest inorganic filler content is present in traditional minifilled composites with the intention of increasing hardness and wear resistance $\mathrm{e}^{3,17}$.

Microfilled composite resins contain small filler particles and little amount of filler, which improve surface smoothness and the quality of polishing ${ }^{21}$. In the last decade, a new concept of composite resin, the flowable composite resin, was introduced in the dental market. This material presents modifications in viscosity and modulus of elasticity. Nevertheless, few researches about the influence of polishing intervals on surface hardness of flowable composites were reported. Considering this lack of information, the aim of the present study was to assess in vitro the surface hardness of flowable composite resins before and after polishing at different times, as compared to a microfilled and a minifilled composite resin.

\section{MATERIALS AND METHODS}

For this study, six composite resins were used: Revolution, Natural Flow, Fill Magic Flow, Flow-it! (flowable composites), Silux Plus (microfilled composite) and Z100 (minifilled composite). The tested materials and their manufacturers and characteristics are displayed in Table 1.

A total of 240 specimens were prepared - 40 per material and 10 for each tested interval. Initially, polyester resin cylinders with $1 / 4$ inch diameter and $10 \mathrm{~mm}$ high were obtained. The cylinders were finished with \#280 to \#400-grit silicon carbide paper to obtain a flat surface. Then, cavities $(1.4 \mathrm{~mm}$ deep $5 \mathrm{~mm}$ in diameter) were prepared in the middle of cylinders with a wheel-shaped \#4054 diamond bur.

The tested materials were inserted into the cavities in a single increment. A transparent polyester matrix strip was positioned on the material/cylinder surface and then a glass slide was gently pressed to obtain a flat and smooth surface. Each material was cured for $40 \mathrm{sec}$ with a visible light-curing unit with $500 \mathrm{~mW} / \mathrm{cm}^{2}$ output (XL 3000, 3M Dental Products, St. Paul, MN, USA) following the manufacturers' instructions.

Vickers hardness (VHN) was evaluated using a microindentation tester (HMV-2, Shimadzu Co., Kyoto, Japan). For each specimen, three indentations were accomplished with a $50 \mathrm{~g}$ load applied for $30 \mathrm{sec}$, and the means were calculated in VHN. Measurements were recorded at different times: immediately, 24 hours, 7 days and 21 days after preparation of the samples, before and after polishing.

TABLE 1- Tested materials

\begin{tabular}{|c|c|c|c|c|c|}
\hline Material & Manufacturer & $\begin{array}{l}\text { \# Batch } \\
\text { Number }\end{array}$ & Filler & $\%$ (vol) & $\begin{array}{l}\text { Filler Size } \\
\qquad(\mu \mathrm{m})\end{array}$ \\
\hline Revolution & $\begin{array}{l}\text { Kerr Corp. } \\
\text { Orange, CA, USA }\end{array}$ & 905255 & Barium glass, synthetic silica & $55 \%$ & 1.0 \\
\hline Natural Flow & $\begin{array}{l}\text { DFL Ind. e Com. Ltda. } \\
\text { Rio de Janeiro, RJ, Brazil }\end{array}$ & 9908730 & $\begin{array}{l}\text { Boron-aluminum silicate glass, } \\
\text { synthetic silica }\end{array}$ & $43 \%$ & ns \\
\hline Flow It! & $\begin{array}{l}\text { Jeneric-Pentron Inc. } \\
\text { Wallinford, CT, USA }\end{array}$ & 26653 & Barium-boron-fluor-silicate glass & $55 \%$ & 1.5 \\
\hline Fill Magic Flow & $\begin{array}{l}\text { Vigodent S/A Ind. e Com. } \\
\text { Rio de Janeiro, RJ, Brazil }\end{array}$ & 01199 & Barium aluminum silicate & ns & 0.7 \\
\hline Silux Plus & $\begin{array}{l}\text { 3M Dental Products } \\
\text { St. Paul, MN, USA }\end{array}$ & 19990915 & Colloidal silica & $40 \%$ & 0.04 \\
\hline Z100 & $\begin{array}{l}\text { 3M Dental Products } \\
\text { St. Paul, MN, USA }\end{array}$ & 9GM & Zirconia-silica & $70 \%$ & 0.7 \\
\hline
\end{tabular}

ns-not supplied by the manufacturer. 
Specimens were stored in distilled water at $37^{\circ} \mathrm{C}$.

For standardization, polishing was performed by the same operator using Super-Snap disks (Shofu Inc., Kyoto, Japan) in decreasing abrasive order, each one applied for 10 seconds.

Data were submitted to statistical analysis using threeway ANOVA and Tukey test at 0.05 significance level.

\section{RESULTS}

The means and standard deviations, before and after polishing, of all study groups are shown in Table 2 .

The analysis of factors showed significant differences among composite resins, polishing and time. For the factor composite resins, it can be observed that, although the flowable composite resins yielded the lowest means, no statistically significant difference was observed among the different trademarks. Z100 minifilled composite showed statistically higher hardness values than the other tested materials $(\mathrm{p}<0.01)$, irrespective of time and polishing. Silux microfilled composite provided higher hardness $(\mathrm{p}<0.01)$ than the flowable composites. Comparing the composite resins and time, it can be verified that Silux showed similar behavior than Fill Magic for 24h.

The factor polishing influenced the hardness of all tested materials $(\mathrm{p}<0.01)$. Therefore, in general, polishing provided an increase in microhardness. When the different polishing intervals were analyzed, the interaction of composite resins and time, using the Tukey test, showed a gradual and statistically significant increase $(\mathrm{p}<0.05)$ in surface hardness. In the overall analysis of data, the highest hardness values were reached when polishing was accomplished 7 days after preparation of specimens, except for the Fill Magic Flow.

\section{DISCUSSION}

Hardness determines the degree of deformation of a material and it is generally accepted as an important property and a valuable parameter of comparison with the tooth structure. Changes in this property can be ascribed to the polymerization or maturation status of restorative materials ${ }^{30}$. Enamel and dentin Vickers hardness values were stated as $348 \mathrm{VHN}$ and $80 \mathrm{VHN}$, respectively ${ }^{23}$.

To assure an optimized clinical performance of restorations, it is of paramount importance to employ materials with hardness at least similar to that of the dentinal substrate, not only superficially, but also in depth, since an accentuated decrease in hardness would adversely affect their mechanical properties and marginal integrity ${ }^{4,19}$. In the present work, a gradual and significant increase in surface hardness was observed with regard to time, but regardless of the accomplishment of polishing.

TABLE 2- Means and standard deviations (in parenthesis) of surface hardness (VHN) of the tested materials, before and after polishing at different times- I (immediately), 24h (24 hours), $7 \mathrm{~d}$ (7 days), 21d (21 days)

\begin{tabular}{|c|c|c|c|c|c|c|}
\hline \multirow[b]{2}{*}{$\begin{array}{l}\text { PERIOD } \\
(\mathrm{n}=10)\end{array}$} & \multirow[b]{2}{*}{$\begin{array}{l}\text { Revolution } \\
(n=40)\end{array}$} & \multirow[b]{2}{*}{$\begin{array}{l}\text { Natural Flow } \\
\qquad(n=40)\end{array}$} & \multicolumn{2}{|c|}{ MATERIAL } & \multirow[b]{2}{*}{$\begin{array}{l}\text { Silux } \\
(n=40)\end{array}$} & \multirow[b]{2}{*}{$\begin{array}{l}Z 100 \\
(n=40)\end{array}$} \\
\hline & & & $\begin{array}{l}\text { Flow-it! } \\
(n=40)\end{array}$ & $\begin{array}{l}\text { Fill Magic Flow } \\
\qquad(n=40)\end{array}$ & & \\
\hline I-before & $\begin{array}{l}20.05 \\
(2.62) \mathrm{d}\end{array}$ & $\begin{array}{l}20.60 \\
(0.94) c \bullet\end{array}$ & $\begin{array}{l}22.33 \\
(2.78) \mathrm{c} \bullet\end{array}$ & $\begin{array}{l}28.95 \\
(2.88) \mathrm{d}\end{array}$ & $\begin{array}{l}35.03 \\
(1.88) \mathrm{cd} A\end{array}$ & $\begin{array}{l}99.47 \\
(4.06) \mathrm{c*}\end{array}$ \\
\hline I-after & $\begin{array}{l}27.38 \\
(2.52) \mathrm{ab} \bullet\end{array}$ & $\begin{array}{l}29.93 \\
(2.78) \mathrm{a}\end{array}$ & $\begin{array}{l}29.08 \\
(3.01) \mathrm{b} \bullet\end{array}$ & $\begin{array}{l}30.43 \\
(3.66) \mathrm{d} \bullet\end{array}$ & $\begin{array}{l}35.92 \\
(1.33) \mathrm{cd}\end{array}$ & $\begin{array}{l}96.53 \\
(9.10) \mathrm{d}\end{array}$ \\
\hline 24h-before & $\begin{array}{l}24.75 \\
(1.68) \mathrm{bc} \bullet\end{array}$ & $\begin{array}{l}21.97 \\
(2.54) \mathrm{c} \bullet\end{array}$ & $\begin{array}{l}25.50 \\
(1.24) c\end{array}$ & $\begin{array}{l}33.95 \\
(4.76) \mathrm{C}\end{array}$ & $\begin{array}{l}33.48 \\
(2.03) \mathrm{d}\end{array}$ & $\begin{array}{l}94.40 \\
(4.76) \mathrm{d} \text {. }\end{array}$ \\
\hline 24h-after & $\begin{array}{l}25.62 \\
(1.65) \mathrm{bc} \bullet\end{array}$ & $\begin{array}{l}29.72 \\
(4.98) \mathrm{a}\end{array}$ & $\begin{array}{l}31.23 \\
(5.41) \mathrm{b}\end{array}$ & $\begin{array}{l}37.60 \\
(1.35) \mathrm{b}\end{array}$ & $\begin{array}{l}38.00 \\
(4.24) \mathrm{bc} A\end{array}$ & $\begin{array}{l}117.5 \\
(7.34) b *\end{array}$ \\
\hline $7 d$-before & $\begin{array}{l}27.93 \\
(0.82) \mathrm{ab}\end{array}$ & $\begin{array}{l}28.61 \\
(1.65) \mathrm{a}\end{array}$ & $\begin{array}{l}30.58 \\
(1.80) \mathrm{b} \bullet\end{array}$ & $\begin{array}{l}29.18 \\
(8.67) \mathrm{d} \bullet\end{array}$ & $\begin{array}{l}39.70 \\
(2.30) b\end{array}$ & $\begin{array}{l}94.28 \\
(2.70) \mathrm{d}\end{array}$ \\
\hline $7 \mathrm{~d}$-after & $\begin{array}{l}29.47 \\
(2.21) \mathrm{a}\end{array}$ & $\begin{array}{l}29.45 \\
(1.82) \mathrm{a}\end{array}$ & $\begin{array}{l}38.23 \\
(5.27) a\end{array}$ & $\begin{array}{l}38.65 \\
(4.81) b\end{array}$ & $\begin{array}{l}44.35 \\
(5.48) \text { a. }\end{array}$ & $\begin{array}{l}140.8 \\
(10.36) \mathrm{a} *\end{array}$ \\
\hline 21d-before & $\begin{array}{l}23.10 \\
(2.42) \mathrm{cd} \bullet\end{array}$ & $\begin{array}{l}25.27 \\
(1.00) b \bullet\end{array}$ & $\begin{array}{l}32.03 \\
(1.97) b\end{array}$ & $\begin{array}{l}37.92 \\
(4.11) \mathrm{b}\end{array}$ & $\begin{array}{l}41.33 \\
(1.53) a b *\end{array}$ & $\begin{array}{l}94.3 \\
(7.71) \mathrm{d}\end{array}$ \\
\hline 21d-after & $\begin{array}{l}25.23 \\
(1.52) \mathrm{bc} \bullet\end{array}$ & $\begin{array}{l}27.72 \\
(1.90) \mathrm{a} \bullet\end{array}$ & $\begin{array}{l}36.28 \\
(3.70) \mathrm{a}\end{array}$ & $\begin{array}{l}43.62 \\
(6.45) \text { a. }\end{array}$ & $\begin{array}{l}43.98 \\
(3.08) \text { an }\end{array}$ & $\begin{array}{l}117.9 \\
(10.38) \mathrm{b} \text {. }\end{array}$ \\
\hline
\end{tabular}

Same letters: statistical similarity - comparison in lines

Same symbol: statistical similarity - comparison in columns 
Composite resins show microscopic alterations as a result of polymerization shrinkage, restoration technique and finishing/polishing procedures, which can lead to the formation of surface and sub-surface microdefects. If present in a significant amount, these structural microdefects can interfere with the material surface smoothness, wear resistance and hardness, thus significantly compromising its longevity and limiting its indication to some clinical situations ${ }^{14,22}$

The findings of this research disclosed that polishing influenced hardness of the tested composite resins, significantly increasing these values. These results were corroborated by another investigation ${ }^{20}$, which also verified the influence of polishing using a minifilled composite resin. Although a smooth surface can be obtained after polymerization, the superficial layer is essentially composed by organic matrix, being hence, less dense than the underlying layer. Thus, the removal of this layer by polishing procedures increases the surface resistance ${ }^{13,16}$.

Apart from hardness, polishing performed immediately after polymerization can also affect marginal integrity, leading to gaps formation at the tooth/restoration interface ${ }^{9,11,12}$. This fact is also inherent to adhesive restorative materials, due to the stress generated by rotary instruments ${ }^{30}$. Moreover, polishing can provide a more permanent deformation-resistant surface and, if polishing is accomplished immediately after polymerization, this incomplete maturation could turn composites more susceptible to the effects of heat generation, thereby decreasing their hardness, since approximately $75 \%$ of the light-curing process occurs in the first 10 minutes, and the curing reaction can continue for a period of up to 24 hours $^{30}$. Delayed polishing also allows the composite resin to become less liable to negative effects of heat created by this procedure $^{30}$.

Other finding observed in this study was the difference in the performance of tested materials. Flowable composites showed inferior results as compared to the microfilled and minifilled resins. For instance, Z100 minifilled composite resin is composed of zirconium-silica filler particles, which provide higher hardness than colloidal silica present in great amount in Silux Plus microfilled composite. Moreover, the amount of organic matrix present in Z100 is lesser than in the other tested resins.

In this work, the tested flowable composite resins presented similar performance and inferior results as compared to the microfilled and minifilled composite resins. However, irrespective of the composite, delayed polishing is recommended for obtaining better mechanical properties.

\section{CONCLUSIONS}

On the basis of these results, and within the limitations of an in vitro study, it may be concluded that:

1- Flowable composite resins showed lower hardness as compared to the microfilled and minifilled, regardless of polishing.
2- Polishing influenced superficial hardness of the composites, and delayed polishing after 7 days provided higher hardness values.

3- Z100 presented the highest hardness before and after polishing at the different evaluated intervals.

\section{ACKNOWLEDGEMENT}

This work was supported by FAPESP (Fundação de Amparo à Pesquisa do Estado de São Paulo) - Grant \# 99/ 06060-6.

\section{REFERENCES}

1- Baseren M. Surface roughness of nanofill and nanohybrid composite resin and ormocer-based tooth-colored restorative materials after several finishing and polishing procedures. J Biomater Appl. 2004;19:121-34.

2- Bayne SC, Taylor DF, Heymann HO. Protection hypothesis for composite wear. Dent Mater. 1992;8:305-9.

3- Bayne SC, Thompson JY, Swift EJJr, Stamatiades P, Wilkerson M. A characterization of first-generation flowable composites. J Am Dent Assoc. 1998;129:567-77.

4- Bouschlicher MR, Rueggeberg FA, Wilson BM. Correlation of botton-to-top surface microhardness and conversion ratios for a variety of resin composite compositions. Oper Dent. 2004;29:698704.

5- Condon JR, Ferracane JL. Evaluation of composite wear with a new multi-mode oral wear simulator. Dent Mater. 1996;12:218-26.

6- Correr Sobrinho L, Góes MF, Consani S, Sinhoreti MA, Knowles JC. Correlation between light intensity and exposure time on the hardness of composite resin. J Mater Sci. 2000;11:361-4.

7- de Gee AJ, Pallav P, Werner A, Davidson CL. Annealing as a mechanism of increasing wear resistance of composites. Dent Mater. 1990;6:266-70.

8- Ferracane JL, Mitchem JC, Condon JR, Todd R. Wear and marginal breakdown of composites with various degrees of cure. J Dent Res. 1997;76:1508-16.

9- Han L, Okamoto A, Fukushima M, Okiji T. Enamel microcracks produced around restorations with flowable composites. Dent Mater J. 2005;24:83-91.

10- Helvatjoglou-Antoniadi M, Papadogianis Y, Koliniotou-Kubia E, Kubias S. Surface hardness of light-cured and self-cured composite resins. J Prosthet Dent. 1991;65:215-20.

11- Irie M, Tjandrawinata R, Suzuki K. Effect of delayed polishing periods on interfacial gap formation of class $\mathrm{V}$ restorations. Oper Dent. 2003;28:552-9.

12- Irie, M.; Suzuki, K. Marginal seal of resin-modified glass ionomers and compomers: Effect of delaying polishing procedure after oneday storage. Oper Dent. 2000;25:488-96.

13- Joniot SB, Gregoire GL, Auther AM, Roques YM. Threedimensional optical perfilometry analysis of surface states obtained after finishing sequences for three composite resins. Oper Dent. 2000; 25:311-5 
14- Krejci I, Lutz F, Boretti L. Resin composite polishing - filling the gaps. Quintessence Int. 1999;30:490-5.

15- Leinfelder KF, Beadreau RW, Mazer RB. An in vitro device for predicting clinical wear. Quintessence Int. 1989;20:755-61.

16- Lim CC, Neo J, Yap A. The influence of finishing time on the marginal seal of a resin-modified glass-ionomer and polyacid-modified resin composite. J Oral Rehabil. 1999;26:48-52.

17- Manhart J, Kunzelmann KH, Chen HY, Hickel R. Mechanical properties of new composite restorative materials. J Biomed Mater Res. 2000;53:353-61.

18- McCabe JF, Wassell RW. Hardness of model dental composites the effect of filler volume fraction and silanation. J Mater Sci. 1999;10:291-4

19- Obici AC, Sinhoreti MA, Sobrinho L, Góes MF, Consani S. Evaluation of depth of cure and Knoop hardness in a dental composite photo-activated using different methods. Braz Dent J. 2004;15:199203.

20- Park S, Krejci I, Lutz F. Hardness of celluloid strip-finished or polished composite surfaces with time. J Prosthet Dent. 2000;83: 660-3

21- Rada RE. The versatility of flowable composites. Dent Today. $1998 ; 17: 78-81$

22- Roeder LB, Tate WH, Powers JM. Effect of finishing and polishing procedures on the surface roughness of packable composites. Oper Dent. 2000;25:534-43.

23- Ryge G, Foley DE, Fairhurst CW. Micro-indentation hardness. J Dent Res, 1961;40:1116-26.

24- Stanford WB, Fan PL, Wozniak WT, Stanford JW. Effects of finishing on color and gloss of composites with different fillers. J Am Dent Assoc. 1985;110:211-3.

25- Suzuki S, Leinfelder KF, Kawai K, et al. Effect of particle variation on wear rates of posterior composites. Am J Dent. 1995;8:173-8.

26- Von Fraunhofer JA, Curtis PJr. The physical and mechanical properties of anterior and posterior composite restorative materials. Dent Mater. 1989;5:365-8.

27- Wassell RW, McCabe JF, Walls AWG. Wear rates of regular and tempered composites. J Dent. 1997;25:49-52.

28- Wilson F, Heath JR, Watts DC. Finishing composite restorative materials. J Oral Rehabil. 1990;17:79-87.

29- Yap AU, Wu SS, Chelvan S, Tan ES. Effect of hygiene maintenance procedures on surface roughness of composite restoratives. Oper Dent. 2005;30:99-104

30- Yap AUJ, Sau CW, Lye KW. Effects of finishing/polishing time on surface characteristics of tooth-coloured restoratives. J Oral Rehabil. 1998;25:456-61. 